\author{
Andreas KINNEGING \\ University of Leiden, The Netherlands \\ a.a.m.kinneging@law.leidenuniv.nl
}

\title{
DEMOCRACY TEMPERED \\ BY ARISTOCRACY: \\ RETHINKING AN OLD IDEA
}

ABSTRACT This article retakes an argument that has ancient roots, but is nowadays largely forgotten, namely that democracy, to be viable and stable, stands in need of aristocratic checks. First of all, institutional checks, like an Upper House in Parliament, and a professional judiciary. But more importantly - and that is what the article focuses on - an aristocratic ethos in the rulership or leadership. The tradition of reflection on the aristocratic ethos, going back to antiquity, is described, including the virtue theory it propounds. Finally, an overview is given of the traditional ideas on how to create and ensure the influence of the aristocratic ethos over the rulers or leaders.

Keywords: democracy, aristocracy, aristocratic ethos, idea of gentility, virtue theory, rulership, leadership 


\section{INTRODUCTION: THE THESIS DEFENDED}

Today, aristocracy is a topic of interest mainly to academic historians. If the subject comes up at all in other contexts, the attitude is generally negative: the aristocracy was the ruling class of the ancien régime that has fortunately ended. In the West, we now have a democracy, based on liberty and equality, which is the only good and just political order there is. This is the general opinion.

The general opinion, however, is often wrong, or, at best, only half-true. One is tempted to ask whether the ancien régime was really that bad Perhaps it was in some respects better than the new regime. Is the dominant view of the past based on facts, or is it based on the wish to legitimize our own political order? To what extent is the present order the only good and just political order possible? These are all important questions, and questions that certainly should be asked in academia; but they are hardly ever asked. After all, we supposedly live in the best of all times and have the best of all political orders: democracy. ${ }^{1}$

Let us assume for now that we do indeed live in the best of all times and under the best of all political orders. In that case, unless one were to believe that our political order will never end, the question arises: how we preserve democracy? How do we preserve democracy it for as long as possible? For that democracy will come to an end is inevitable, since everything under the sun changes, provided one waits long enough. Everything comes into existence and vanishes again, sometimes quickly, sometimes after a long lapse of time. If we use history to make a prognosis, then democracy's life expectancy is not very good. Democracy in ancient Greece, particularly in Athens, lasted all of two centuries, from $500 \mathrm{BC}$ to $300 \mathrm{BC}$. Before and after that experiment in self rule, we find only other types of political order, mostly either monarchical or aristocratic. The transience of ancient democracy indicates how pressing the question of how to preserve democracy is. It is a question that must be posed.

A look at the relevant literature quickly reveals that the question is indeed posed. It also reveals where the answer is sought. Democracy is to be assured first of all by clever institutional design. Fundamental rules that determine the way the system works, whether or not they are part of a written constitution, have to be designed in such a way that the system is truly democratic. This basic approach raises questions about electoral systems; the powers of the various political bodies; the influence of third parties, such as lobbies and companies; the role of the courts; the pros and cons of referenda, etc., all of which are geared to the aim of making democracy work as well as possible. ${ }^{2}$

An endlessly repeated proof of this "fact" is a famous remark by Churchill, made in the House of Commons, on November 11 th 1947, that democracy is the worst form of government except for all those other forms that have been tried from time to time.

A. Lijphart, Patterns of Democracy. Government Forms and Performance in Thirty-Six Countries, New Haven 1999; M.J.C. Vile, Politics in the USA, London-New York 2007; G. Sartori, The Theory of Democracy Revisited, Vol. 1-2, Chatham, N.J. 1987. 
This approach also fosters a second set of more fundamental questions on the nature of democracy itself. One such question is the age-old issue of will versus reason. As Jefferson said in his first inaugural address on March $4^{\text {th }}$ 1801: Although the will of the majority is in all cases to prevail, that will to be rightful, must be reasonable. Thus we may ask what we can do to ensure that the will of the majority is reasonable, and what we can do if it is not. Yet another, related question arises over majority rule versus individual and minority rights, also known as the question of the tyranny of the majority. ${ }^{3}$ If the will of the majority is not reasonable, and does not respect individual and minority rights, democracy becomes oppressive a tyranny of the majority, or it may fall apart in a civil war.

One standard solution to this problem is, interestingly, the introduction of aristocratic institutions, to complement other, more democratic institutions. ${ }^{4}$ The most conspicuous of these proposals involves a senate and a judiciary, with substantial powers, appointed for life. The idea behind such suggestions is that democracy, in order to work properly, paradoxically needs some aristocratic institutions as well.

While the significance of institutional design for the success of a democracy is beyond doubt, it is not a panacea. Even the best institutional design will remain nothing more than a theoretical paper idealif it is not accompanied by and carried out with a certain ethos. Dozens of democratic constitutions have been set up in the past century have come to naught within a few years. One could think not only of the failed democracies in post-colonial Africa, ${ }^{5}$ but also of the fate of the Weimar Republic. ${ }^{6}$ Why did these democracies end? The answer, or part of the answer at least, is that they lacked the ethos necessary to breathe life into their carefully designed democratic institutions.

What exactly is an ethos? It is a set of intellectual and moral dispositions, capacities, and virtues. It is a mentality, a character. An ethos is more than just a set of preferences. Even if a people unanimously prefer democracy, that is no guarantee that democracy will work for this people. The crucial variable is the intellectual and moral character of a people. They need to have virtues of a specific type to make the democratic institutions work the way they are supposed to work.

This is a point often made and generally recognized as true. The question is, of course, what ethos precisely is needed in a democracy. The answer generally given is a democratic ethos. Such an assertion is evidently true - there can be no functioning democracy without a democratic ethos. (Further down we will discuss what virtues this

A concern classically expressed in Tocqueville's Democracy in America, Vol. 1 (1835).

4 See e.g. the discussion in the Federalist Papers no. 62-64 and no. 78, on the Senate and the Judiciary, Tocqueville's reflections in Democracy in America, I.2.8 par. 2, on the spirit of the lawyer as a counterweight to democracy, and in J.S. Mill, Considerations of Representative Government, ch. VII, on the necessary presence of the moral and intellectual elite of the country in the representative organs. All such views hark back to the old theory of mixed government, that dominated Western political theory from the ancient Greeks until the Enlightenment. See for an overview: A. Riklin, Machtteilung. Geschichte der Mischverfassung, Darmstadt 2006.

5 M. Meredith, The State of Africa; a History of the Continent since Independence, London 2005.

6 R. Evans, The Coming of the Third Reich, New York 2005. 
implies.) The real question, however, is to what extent such an ethos must exist - many Germans in 1945 did not have a democratic ethos, and yet West-Germany became a successful democracy. Apparently, it is not necessary that all citizens of a democracy possess a democratic ethos. It seems undeniable, however, that at least some influential segments of society must have it, if democracy is to survive and do its job.

So a democratic ethos is necessary. One can, however, have doubts as to whether such an ethos is sufficient. Just as it is maintained that, on the institutional level, democracy can work well only if it is complemented by some aristocratic institutions, likewise one could argue that democracy, if it is to survive and prosper, needs an aristocratic ethos to complement and counterbalance the democratic ethos. That is the thesis of this essay. If it is true, contrary to prevailing opinion, the idea of aristocracy is quite relevant to our democratic age, and to everyone interested in the question how to preserve democracy.

The following will first discuss democracy and its shortcomings. Subsequently, it will set out what the aristocratic ethos stands for and how it can mend the shortcomings of democracy, helping it to function more properly. Finally, a conclusion will summarize the most important findings and add a caveat. First, however, we must remind ourselves of some straightforward sociological truths that are nevertheless often disregarded.

\section{MOSCA'S REMINDER}

A democracy is commonly seen, in Lincoln's famous words, from his Gettysburg Address (1863), as a government of the people, by the people, for the people, and as such is the very antithesis of the supposedly traditional form of government: a privileged class ruling over the people. The simple truth is, however, that the people never govern themselves. ${ }^{7}$ Gaetano Mosca's brilliant Elementi di Scienza Politica, first published in 1896, forcefully drives this point home. ${ }^{8}$ His basic insight is simple. There is no human organization without ranking and subordination. It is always the case that some command, and others obey. ${ }^{9}$ This, he says, is as true in politics as it is in other spheres: In all societies - from societies that are very meagerly developed and have barely attained the dawning of civilization, down to the most advanced and powerful societies - two classes of people appear - a class that rules and a class that is ruled. The first class, always the less numerous, performs all political functions, monopolizes power and enjoys the advantages that power brings, whereas the second, the more numerous class, is directed and controlled by the first, in a manner that is now more or less legal, now more or less arbitrary, and violent... ${ }^{10}$

R. Aron, Les sociétés modernes, Paris 2006, p. 546 (Quadrige. Grands Textes).

8 English translation by Hannah Kahn, entitled The Ruling Class, edited and revised by Arthur Livingstone, McGraw-Hill, 1939. This work is a must-read. Mosca is generally quoted as one of the founders of "democratic elitism", the other being Vilfredo Pareto, Robert Michels, Max Weber, and Joseph Schumpeter.

$9 \quad$ Ibid., p. 397.

10 Ibid., p. 50. 
Moreover, the ruling class always consists of two layers, Mosca explains. Below the highest stratum there is another one, which is much more numerous. It is on the qualities of this secondary stratum that the social and political order really depends, much more so than on the highest. Mosca draws a parallel with the army: The strength of an army depends primarily on the intellectual and moral valor of the officers who come into direct contact with the soldiers, beginning with the colonel and ending with the second lieutenant. If, by some improbable accident, all the generals and staff officers of an army were to disappear at one stroke, the army would sustain a very serious shock, but it would still be on its feet and the lost leaders could be replaced in a few months' time by promoting the better regimental commanders and raising other officers, from among the more competent, to the staff. But if all the officers who actually lead the soldiers were to disappear, the army would dissolve before they could possibly be replaced. ${ }^{11}$

The ruling class is never unified. There are always different factions within it, fighting for predominance. In court society these are principally court cliques, in modern democracy, political parties. ${ }^{12}$ But these factions always find many other venues in which to conspire against each other.

Just as the ruling class will never be a cohesive whole, so too will it never be completely closed to social climbers. Mosca notes that the tendency to replenish ruling classes from below [...] is constantly at work with greater or lesser intensity in all human societies. ${ }^{13}$ This was as true in earlier eras as it is in our own. Contrary to popular belief, the French nobility of the ancien régime, for instance, was relatively open, as is witnessed by the fact that the great majority of noble families in the eighteenth century were of recent origin. ${ }^{14}$ Today, of course, the three generations it took to become a gentleman and access the ruling class will be judged to betray a scandalous lack of openness. Modern democrats believe that high office should in principle be open to all individuals who qualify for it, regardless of their social background, though in practice this is still far from the case, even today.

Mosca is clearly right, and we are stuck with a ruling class, regardless of the form of government. This is hard for any democrat to admit, for his first article of faith is that everyone is equal. To reduce the discomfort, rulership is clothed in different, democratically more acceptable names, the most fashionable of which at present is "leadership." According to the contemporary belief, rulership is a characteristic of undemocratic systems; leadership, on the other hand, is something democracies have. But a rose is a rose by any other name, and so is the ruling class.

Since all governments must have a ruling class, the question arises what the nature of this ruling class is. There is obviously no guarantee that it will be a good ruling class.

$11 \quad$ Ibid., p. 405.

12 Ibid., p. 410.

13 Ibid., p. 413.

14 C.B.A. Behrens, Society, Government, and the Enlightenment. The Experiences of Eighteenth-Century France and Prussia, New York 1985, pp. 47-55; G. Chaussinand-Nogaret, La noblesse au XVIIIe siècle. De la féodalité aux lumières, Paris 1976, passim; A.A.M. Kinneging, Aristocracy, Antiquity, and History. Classicism in Political Thought, New Brunswick, N.J. 1997, ch. II. 
Men are no angels, as Madison felicitously expressed it in Federalist Paper no. 51. They are born with all the human frailties: pride, sloth, vanity, cupidity, anger, etc. Indeed when we consider that political power sometimes requires the use of violence, and deception, and that it poses to its possessors great temptations to vice, it becomes obvious that the odds are heavily against good and in favor of bad rulership. History provides more than enough empirical proofs of this, not only in autocratic but also in democratic systems. All people want good rulers. The question is - and it is an important one - how do we get them?

\section{DEMOCRACY IN THEORY AND REALITY}

Do democratic institutions ensure good rulership? One of the classic arguments for democracy is that it enables us - the ruled - "to send the bastards home" - the latter being rulers who turn out to be bad. This argument is central to the age-old republican idea, going back to the ancient Greeks and Romans, that accorded citizens the institutional power to check the officeholders and vote them out. Democracy, in this sense, is simply the extension of this civic status, of old the exclusive privilege of male freemen, to the entire adult population.

Notice that, defined in this way, democracy is not self-government. It presupposes a ruling class and a class that is ruled. What this concept of democracy contends is that those ruled over should have the means to get rid of the rulers, so that the rulers will have a powerful incentive to advance the interests of the ruled. If the self-interest of the rulers is not connected to the interest of the ruled by such institutional design, it is to be feared, given the frailties inherent in human nature, that the rulers will generally disregard the interest of the ruled in favor of their own interest. ${ }^{15}$

The Machiavellianism of this view has a certain intuitive appeal. It is seemingly built on the low but secure ground of the self-interest of rulers and the ruled. No virtues on either side seem to be necessary. But is this true? A closer look at the facts reveals that matters are not that simple. The check on the rulers by the ruled works if the people have a certain ethos, certain virtues. First, the people must be well informed about what the rulers do and where their own interests lie. That means that they must shake off their ignorance and apathy. They must be willing to take an active interest in public affairs and spend time necessary to gain enough knowledge to make reasonable and true judgments on all important matters of politics and public administration. Second, the people should have a heartfelt concern for the common interest at all times.

All intelligent theorist of democracy, past and present, are aware of these two requirements of the system: knowledge and public spiritedness, For this reason, democ-

15 This is the main argument of Federalist Paper, no. 51. The abuse of government being quite likely, since those who govern are no angels, it is imperative to have several controls on the government, the primary being a dependence on the people. And although Publius admits the need of virtue in those who govern, the emphasis in the Federalist Papers is on controls. 
racies place great emphasis on civic education. Such an education is prerequisite if the people are to be good citizens, that take a knowledgeable, active role in the res publica and put aside their private interest for the common good. ${ }^{16}$

The Machiavellian argument that democracy relies entirely on the self-interest of the ruled to check the self-interest of the rulers and requires no personal virtue is thus unviable. ${ }^{17}$ Democracy can only be a check on the rulers if the ruled have the ethos - if they have the virtues. As a consequence, the real question is whether the ruled will ever acquire this ethos, these virtues, whether they will ever become good citizens. Is it realistic to expect that the masses can be turned into well-informed, public-spirited citizens? Historical evidence provides every reason to be pessimistic about that.

As far as the first prerequisite is concerned, in reality, most people's knowledge of what rulers actually is generally extremely superficial.This is not that strange. After all, people have other, more urgent things to do, and can spend very limited time learning about what is going on in politics and public administration. Additionally, they have no power or influence whatsoever as individuals, so there is little motivation to form a knowledgeable opinion. As far as their family, work, or immediate surroundings are concerned, people are generally well aware of what is in their interest, and although errors of judgment occur, they are mostly able to prioritize various goals. When it comes to the big decisions that need to be made in politics and public administration, however, it becomes very hard, if not impossible for them to say what is in their interest. ${ }^{18}$ An example: Should the Greeks stay in the euro zone?

When it comes to these matters, the typical individual is reduced to a level of mental performance he himself would regard as infantile within the sphere of his family, work, and immediate surroundings. He argues and analyzes in a primitive way, mainly associative and affective. ${ }^{19}$ Because he does not understand the political realities, he will yield to unreasonable impulses and prejudices more readily than in his personal life, which sometimes results in meanness and inhumanity. "Close all the borders" - buta at other times in an equally reprehensible over-generosity and naïve trust in his fellow men - "Let everyone in."

When converted into votes, such impulses and prejudices have very damaging consequences. ${ }^{20}$ Moreover, this infantilism is the window of opportunity for all kinds of demagogues to flatter the masses, tell them lies, play to their sentiments, and exploit

16 J. Dewey, Democracy and Education. An Introduction to the Philosophy of Education, New York 2016 (Text-Book Series in Education); A. Gutmann, Democratic Education, Princeton 1999.

17 For concrete historical cases of such failure, see the literature mentioned in notes 5 and 6 .

18 W. Lippmann, The Phantom Public, New Brunswick 1993 (1927) is now even more pertinent than when it was published.

19 This is a somewhat modified citation of J. Schumpeter, Capitalism, Socialism, and Democracy, London-New York 1994 (1943), ch. 21c, p. 262. As in the case of Mosca, we would profit a lot if we were to read Schumpeter as much as we drop his name. Chapter 21c, pp. 256-264, is called "human nature in politics". It should be obligatory for all students of democracy. See also G. Mosca, The Ruling Class, pp. 411-412.

20 J. Schumpeter, Capitalism..., p. 262. 
and foment their prejudices for their own purposes. As a consequence, the "will of the people" is fabricated rather than authentic. ${ }^{21}$ And even if authentic, it is not reasonable.

As far as the second prerequisite is concerned, a heartfelt concern for the common interest and a readiness to compromise or even sacrifice one's interest for the greater interest and harmony of all, this virtue too is usually lacking. The natural tendency in the individual is to follow his self-interest, at the expense of that of others, while that of the majority is to follow its self-interest at the expense of the interest of the minority and the general public. The latter phenomenon, of course, is known since Tocqueville as the "tyranny of the majority."

Contrary to what some expected, the rise in the general level of education certainly has not improved the civic virtues of the population. ${ }^{22}$ Neither has the overwhelming presence of modern mass media in our lives. ${ }^{23}$ If anything, the overall sense of citizenship seems to have decreased. The infantilism mentioned above is as typical of the ruled as ever. In fact, there are no signs that the ruled will ever overcome their poor understanding of politics. And public spiritedness is probably at an all-time low.

This has an important implication. It means that, in reality, the ruled will never be in a position to adequately check the rulers, not even in a democracy. In reality, there will always be scope for the rulers to misuse their power for their own interest, and contrary to the interest of the ruled. It will always be possible for the rulers, even in a democracy, to subject the ruled to their whims, and to turn citizens into their servants or slaves. Given the flaws inherent in human nature, this is not a mere theoretical possibility. On the contrary, it is quite likely. This is why a democracy needs the aristocratic tradition in political theory.

\section{THE ARISTOCRATIC TRADITION}

The crucial insight of aristocratic theory is the understanding that no institutional controls on government can ever be sufficient to ensure that the ruling class will not misuse its powers. In reality, the misuse of power can be prevented only if, in addition to institutional checks on government, there is a check within the soul of the rulers, a check created by certain intellectual and moral virtues. The fundamental conviction of aristocratic theory is that these virtues are absolutely necessary in the ruling class if a country is to be ruled well. If these are lacking, even a brilliant institutional design will be of little or no avail. ${ }^{24}$ This insight is not limited to monarchy or oligarchy but is of tremen-

$21 \quad$ Ibid., p. 263.

22 D. Allman, M. Beatty (eds.), Cultivating Citizens. Soulcraft and Citizenship in Contemporary America, Lanham 2003 (Applications of Political Theory); D. Anthony, De la République et de la citoyenneté. Le défi démocratique dans la France du XXIe siècle, Besançon 2009.

23 G. Sartori, Homo videns. Televisione epost-pensiero, Roma 1997 (Sagittari Laterza, 107). A book that should have long ago been translated into English.

24 This idea of the need of a check within the soul of the rulers is a straightforward application of the more general idea that man needs to exercise Selbstzwang (Kant), an inner "check" (Babbitt) to stay on 
dous importance also to democracy, given that democracy too has rulers. The central questions of aristocratic political theory stem from this insight. They are, first, "Which virtues should rulers have?" And second: "How are rulers made virtuous?" The aristocratic answer to both questions will be discussed in the following.

But first a note on terminology: ever since they were created by the ancient Greeks, the words "aristocracy" and "aristocratic" have always remained rather academic notions. When used, they referred to the form of government or aspects of it, never to a class, let alone to individuals. Using "the aristocracy," in reference to a class of people, and "an aristocrat," in reference to a person, is no older than the French Revolution. Before that, other words were used to refer to persons and groups we would now call aristocratic. The Greeks, for instance spoke of kalokagathia, the Romans of nobilitas. Not surprisingly, given the influence of Latin, the latter became the standard word in many European countries to refer to the class: nobility, noblesse, nobleza, nobilta, nobreza etc. The Germanic word for nobility is Adel, which was and is used in most of the Northern European countries. When referring to a person, the word became kaloskagathos in Greek nobilis in Latin, nobleman, noble in French, Edelmann in German, ädling in Swedish, etc. But there are other words too. For instance, the word gentleman (gentiluomo, gentilhombre, gentilhomme, dżentelmen, etc.) also signifies a certain nobility or social prestige Hence, the aristocratic tradition in political theory is a tradition concerned with the ideas of nobility and of the gentleman. At the core of these ideas was the notion of good, virtuous rulership.

The literature defending these ideas is vast and nowadays virtually unknown. Contemporary historians distinguish between the literary genres of the "mirrors of princes" and "courtesy literature," thereby inadvertently blinding us to the larger aristocratic tradition of which these are both part. ${ }^{25}$ The mirror of princes books were not merely intended for future kings, nor were such men the only ones reading them. They are ethical treatises intended for all rulers, both great and small. The courtesy books are about noble manners, but manners were traditionally seen as an important part of morals. Thus, we encounter one broad tradition of aristocratic ethics.

To illustrate how old and vast this tradition is, here is an overview of some of the major works on aristocratic ethics: Thomasin von Zerclaere, Der wälsche Gast (1216), Vincent de Beauvais, De eruditione filiorum nobilium (1247-49), Aegidius Romanus, De Regimine Principum (1300), Jakob Wimpfeling, Agatharchia (1498), Erasmus, Institutio Principis (1516), Baldassare Castiglione, Il Cortegiano (1528), Thomas Elyot, The Governour (1531), Johann Sturm, De educatione principum (1551), Giovanni della Casa, Il Galateo (1558), Cyriacus Spangenberg, Adels-Spiegel (1591), Henry Peacham, The Compleat Gentleman (1622), Nicolas Faret, Des Vertus nécessaires à un prince (1623), Nicolas Faret, l'Honnête homme ou l'Art de plaire à la cour (1630), Antoine de Courtin, Nouveau traité de la civilité qui se pratique en France parmi les honnêtes

the right path. See A.A.M. Kinneging, Geography of Good and Evil. Philosophical Investigations, transl. by I. Hardy, ed. by J. Price, Wilmington 2009, p. 17 (Crosscurrents).

25 German historians also speak of Hofliteratur, Regentenspiegel, Prinzenspiegel. 
gens, (1671), Obadiah Walker, Of Education, Especially of Young Gentlemen (1673), John Gailhard, The Compleat Gentleman (1678), Fénelon, Les Aventures de Télémaque (1699), Jean-Baptiste Morvan de Bellegarde, L'Éducation parfaite, contenant les manières bienséantes aux jeunes gens de qualité, et des maximes et des réflexions propres à avancer leur fortune (1713), Friedrich II von Preussen, Anti-Machiavel (1741), Lord Chesterfield, Letters to His Son (1774), Wilhelm Friedrich Rinck, Briefe über Fürstenerziehung (1850). The list could be substantially extended. ${ }^{26}$ Many of these books were very influential in their time. Now, with one or two exceptions, only the specialist has heard of them.

When perusing this literature, a number of characteristics become apparent. First, it is, especially since the fifteenth and sixteenth centuries, overwhelmingly classicist in outlook, that is, focused on the ancient Greeks and Romans, who were seen as exemplary in all things. Of course it was also Christian, but of a rather liberal kind that could be joined with classicism without much tension. There were some within the Christian tradition who protested, most prominently Luther, but to no avail, for the authority of the ancients was too great. ${ }^{27}$ As a result, one finds constant references to the ancients; in fact many books are little more than collections of quotations, stitched together by comments from the author, or a long paraphrase of ancient sources. A closer look at these references, reveals a second common feature: of the many classical authors quoted, three clearly had the most authority - Plato, Aristotle, and Cicero. And of these three, Cicero is the favorite author of the aristocratic tradition, throughout the centuries. ${ }^{28}$

As is generally known, Cicero was a man of many talents and his extant works reflect this breadth. They include many legal and political speeches, a number of rhe-

26 B. Singer, Die Fürstenspiegel in Deutschland im Zeitalter des Humanismus und der Reformation. Bibliographische Grundlagen und ausgewählte Interpretationen. Jakob Wimpfeling, Wolfgang Seidel, Johann Sturm, Urban Rieger, München 1980 (Humanistische Bibliothek. Reihe 1. Abhandlungen, 34), includes an extensive bibliography; F. Lachaud, L. Scordia (eds.), Le Prince au miroir de la littérature politique de l'Antiquité aux Lumières, Mont-Saint-Aignan 2007. On Britain, see J. Carré (ed.), The Crisis of Courtesy. Studies in the Conduct-Book in Britain, 1600-1900, Leiden 1994 (Brill's Studies in Intellectual History, 51), which also includes a bibliography; W.M. Rossetti, Italian Courtesy-Books, London 1869 (Early English Text Society, 8) contains a partial translation and discussion of nine Italian courtesy books. P. Burke, The Fortunes of the Courtier. The European Reception of Castiglione's Cortegiano, Cambridge 1995, discusses the many translations of the most famous of courtesy books. The prototype of all these books should also be mentioned, because it remained influential throughout the ages: Xenophon, Education of Cyrus.

27 See e.g. is Brief an den Christlichen Adel deutscher Nation argued that no book is more contrary to the grace of God and the Christian virtues than Aristotle's Ethics. Away with these books, far from all Christians! His close collaborator Melanchton, however, made sure that all Latin schoolboys in Lutheran countries read Aristotle.

28 Rather a short and superficial overview of Cicero's influence is given in A. Grafton et al. (eds.), The Classical Tradition, Cambridge 2010, pp. 194-197. Idem ditto A. Dyck, A Commentary on Cicero, De Officiis, Ann Arbor 1996, pp. 39-49. The most extensive is still Th. Zielinski, Cicero im Wandel der Jahrhunderte, Leipzing-Berlin 1929. Substantial is also the overview given by P. MacKendrick, The Philosophical Books of Cicero, Duckworth 1995, pp. 258-293. With an appendix on Cicero in America on 294-315. What does it say about the standard view of the American and French Revolutions that Cicero was still very much a living presence in them? 
torical treatises, many letters, and several philosophical works. He also translated some work of Plato and Xenophon, and he wrote poems, but of all these we possess only fragments. Most of the extant works were widely popular for ages, but in fame and influence none surpassed De Officiis. ${ }^{29}$ It was praised for both its content and style, and became a standard grammar school text throughout the West. Hence, every gentleman knew it well. Perhaps the clearest sign of its immense prestige is that it was, after the Bible, the second book in history to be printed..$^{30}$ It gives pause that this once so famous author, and once so famous book, have fallen into virtual oblivion in the past century or so. Few read Cicero at all today him nowadays, outside of the small circle of specialized scholarship, fewer still know De Officiis well.

As for Plato, he was highly esteemed, as he is today, but was also considered difficult, and even abstruse, as he is today. And like today, the Republic was considered to be his magnum opus. It could be found in many a library, even if only in translation. As to Aristotle, finally, he too was highly esteemed, as he still is. And he too was seen as difficult and sometimes abstruse. However, the Nicomachean Ethics were always very popular, even if only in translation. It is then no exaggeration to say that these three authors, and in particular these three books were fundamental to aristocratic views on rulership. They were seen as advocating in essence the same ethos of aristocracy. While it was clear to everyone that they differed in detail, these differences were seen as complementary rather than contradictory.

\section{THE VIRTUES OF THE ARISTOCRATIC SOUL}

So which virtues should a nobleman, a gentleman, a ruler have? Platonic-Aristotelian-Ciceronian virtues. Therefore we cannot focus on the three sources individually must mingle them together in our description of the aristocratic theory of virtue. One cannot but start with Plato, the princeps philosophorum. ${ }^{31}$ There are many ways to construe the theme of Plato's Republic. One of these ways is to say that it is about aristocracy, more specifically about the aristocratic political order, and about the aristocratic man or psyche. ${ }^{32}$ As is still known by some, one of the main arguments of the book is about the structure of this psyche. All psyches are said to consist of three parts - one appetitive, one spirited, and one reasoning. The aristocratic psyche is the psyche in which the reasoning part - the best part - rules, assisted by the spirited part, over the appetitive part - the worst part. Contrary to, for instance, the democratic psyche, in which the appetitive part rules, and the spirited and reasoning parts are its servants. Only the aristocratic psyche is master over itself. It rules itself. And only a man who is master over himself, ought to rule others.

\footnotetext{
Th. Zielinski, Cicero..., p. 66.

30 Simultaneous with the Stoicorum Paradoxa, another of Cicero's works. See A. Grafton et al. (eds.), The Classical Tradition, p. 142.

31 Cicero, De Finibus Bonorum et Malorum, V.7.

32 Republic, $445 \mathrm{~d}$.
} 
Plato's theory of the psyche is complemented by his theory of the virtues. He presents four virtues, and argues that together they constitute the whole of virtue. He defines each of them rather tersly, and ties each of them in with one or more of the parts of the psyche. Wisdom (sophia) or prudence (phronêsis) - Plato does not distinguish between the two - is the virtue of reason. ${ }^{33}$ Fortitude (andreia) is the virtue of the spirited part. While temperance (sôphrosunê) is a virtue of all three parts. If and only if the psyche has all of these three virtues, it will be ordered and harmonious. Every part of the psyche will do what it ought to do. And doing what one ought to do is justice (dikaiosunê), the fourth virtue. So this psyche will be just, and will do what it ought to do, for itself and also unto others.

We will go into this in somewhat more detail below, but even now, it is obvious that some aspects of this theory of virtue are obscure. It must have seemed so even to Plato's own disciples in the Academy. Is it really true that these four virtues are the whole of virtue? What exactly is temperance supposed to mean here? How precisely is order in the psyche related to justice toward others? A strong point, on the other hand, is that, like the parts of the psyche, the virtues are presented as an interrelated system. Plato illustrates how they work together to form a logical whole. He is clearly interested in sketching the underlying structure of virtue, that is clearly what Plato is interested in.

For Aristotle, the structure of the psyche is at most a side issue, with the virtues taking pride of place..$^{34} \mathrm{He}$ produces a much longer catalogue of virtues than Plato's four, and describes each one of them extensively and in a subtle and profound way. On the other hand, there is no sign of any structure, no interconnectedness between the virtues. There are many virtues, splendidly described, but if and how they hang together remains mysterious. Aristotle is silent about it. In sum, one could say that if Plato is strong in systematic thinking, but rather meager as a phenomenologist, Aristotle is a superb phenomenologist, but a poor systematizer.

Cicero is somewhere between Plato and Aristotle, although more toward the side of the latter. The theory of the tripartite psyche, and the corresponding hierarchy among the parts is wholly absent in Cicero's work. ${ }^{35}$ Instead, the reader encounters a wealth of virtues, depicted with great perceptiveness, many of which are of a recognizably Aristotelian descent. ${ }^{36}$ At the same time, however, De Officiis is organized around the four

33 Pace Voegelin, Kahn, Taylor and others. See esp. Republic, 518d-519a.

34 In the whole Nicomachean Ethics (NE) the only extensive discussion is at the end of book I. Neither does it return in De Anima.

35 There are a few remarks, arguing for a two-partite psyche: reason and appetite. See De Officiis, I.101, I.132 Cf. Tusculanae Disputationes, IV.10-11, where it is argued that Plato divided the soul in two parts, one rational and one containing the stormy emotions of anger and desire!

36 Cicero had good knowledge of Plato's works, including the Republic, although it was a gentleman's and not a scholar's knowledge. About his knowledge of Aristotle, however, much is uncertain. Cicero knew Aristotle's exoteric works well, that is for sure. But how well he knew the esoteric treatises, i.e. the Aristotle we know, cannot be determined with certainty. The Nicomachean Ethics, however, is mentioned, albeit only once, but in a way that suggests that he knew it (cf. De Fin., V.12). As to the Eudemian Ethics, which is sometimes argued to have been the standard text of Aristotle's ethics until the first century p.C. it is never mentioned by Cicero. Even if Cicero had no direct knowledge of either of 
Platonic virtues, which become the "cardinal" virtues, that is the virtues on which the whole of life "hinges." ${ }^{37}$ All other virtues, most of which are derived from Aristotle, are given a place within the system of the four cardinal virtues. And it is on the basis of this Platonic-Aristotelian organization of the virtues that Cicero outlined and defined the aristocratic soul - a vision that was at the heart of aristocratic thinking for centuries.

So what virtues are expected of a gentleman? First, Cicero states in De Officiis, he must have the virtues of wisdom (sapientia) and prudence (prudentia) which perform the task of investigating and discovering the truth. ${ }^{38}$ The foremost of the virtues is wisdom, Cicero argues, which is the knowledge of all things human and divine, a cliam replicating Aristotle's estimation of sophia. Prudence, practical wisdom, called phronêsis by Aristotle, is the knowledge of what things to pursue and to avoid..$^{39}$ Aristotle ranks this practical wisdom of phronêsis lower than the theoretical wisdom of sophia. ${ }^{40}$

In a gentleman's education, however, the emphasis would be on prudence, rather than wisdom, since his purpose of life, at least his life, is ruling, not theoretical contemplation. In this inversion of the Aristotelian ranking between wisdom and prudence, aristocratic thought had Cicero on its side, who, notwithstanding his Aristotelian claim that wisdom is foremost, frequently argues that learning and reflection are deficient and incomplete if not resulting in action. ${ }^{41}$

If contemplation and action are entirely different, so are action and production. The latter requires yet another type of knowledge, what we would call technical or instrumental. It is knowledge of how to do things in order to achieve specific goals. This type of knowledge is fitting for the common man, for those who are ruled by others. They do not set the goals, and therefore do not have to think about them. Ruling is first of all thinking about goals, which things to pursue and to avoid. ${ }^{42}$ One needs prudence to do that well.

Next in De Officiis is an account of a nameless virtue, which holds together human society and communal life, and has two parts, justice and beneficence. This is Plato's justice, but heavily modified. Plato's "doing what one ought to do," i.e. rendering what is owed, is still the general denominator, ${ }^{43}$ but where Plato hardly specifies it, Cicero tells

Aristotle's moral treatises, however, he had at least some knowledge of Aristotle's ethics, derived from the exoteric works, and "secondary" sources, Peripatetic and other.

37 From cardo, hinge. The name goes back to St. Ambrose.

38 De Off., I.15.

39 Ibid., I.153.

40 NE 1141a20-23.

${ }^{41}$ De Off, I.153; cf. I.19. This is strongly reminiscent, of course, of what Plato says in the Republic about the philosopher-kings' duty to rule. See 540a-b.

42 NE VI.5: prudence is the ability to deliberate well on what conduces to the good life i.e happiness. Political prudence, the prudence of the rulers, is concerned with the good life of all. Some scholars, picking up on a few remarks of Aristotle, argue that such deliberations are about means, not goals. I believe that to be a non-issue. Every question what to do is prudential, because concerned with goals. Every question how to do it is technical, because concerned with ways and means. 
us that justice is harming no one, unless provoked by injustice, and helping others who are harmed, if one can. ${ }^{44}$ This differs substantially from Aristotle's description of justice in the Nicomachean Ethics. In "harming no one," one recognizes Aristotle's corrective (diorthôtikon) justice, but his distributive (dianemêtikon) justice has disappeared. Instead we get "helping others who are harmed." To this Cicero adds beneficence which, he says, can also be called kindness (benignitas) or liberality (liberalitas). ${ }^{45}$ Beneficence is the second, crucial part of the same virtue that preserves the fellowship and agreement between men. One is reminded of Aristotle's liberality and magnificence, but unlike these Cicero's beneficence is not exclusively financial. One can exhibit beneficence by serving others in nonmonetary ways. ${ }^{46}$

The third virtue of De Officiis is magnitude of soul (magnitudo animi), which takes the place of Plato's fortitude (andreia). Again, Aristotle's influence is apparent: the word is a literal translation of his megalopsuchia but there is a significant difference in the meaning. ${ }^{47}$ Aristotle treats andreia and megalopsuchia as different virtues. He defines andreia as the capacity to withstand what is painful, like fear, given that definition the common translation "courage" is appropriate. ${ }^{48}$ Plato, on the other hand, defines andreia as the capacity to withstand painful and pleasurable things. ${ }^{49}$ Thus, fortitude is a better translation than courage in this case, since fortitude also applies to the temptations of pleasure. Now, Cicero defines magnitudo animi along the lines of Plato's definition of andreia: strength in the face of any difficulty, either painful or pleasurable. In fact, Cicero's greatness of soul is more or less equivalent to Plato's andreia, although his description of it is Aristotelian in its subtle and manifold specification.

Finally, we have the virtue of seemliness or decorum in De Officiis, ${ }^{50}$ which replaces Plato's temperance (sôphrosunê). In the Republic this virtue is defined, with characteristic terseness, as the friendship and accord of all the parts of the psyche, as a result of an agreement that the reasonable part should rule. ${ }^{51}$ This definition is rather obscure and moreover, makes Platonic temperance look (too) much like Platonic justice. ${ }^{52}$ Aristotle takes a different approach, defining temperance as the capacity to withstand what is pleasurable, and thus as complementary to courage. ${ }^{53}$

44 De Off., I.20, I.23. The text at I.20 states that one should harm no one except when provoked by injustice, and common things should be used for common things, whereas private things should be used as one's own. Which of course is something else than helping others, who are harmed.

Ibid., I.20; I.42.

Ibid., II.65-85.

NE, 1124a5-1125a17; De Off., I.61-92.

NE, 1117a30-1117b1.

Republic, 442c.

De Off., I.93-151.

Republic, 442c-d.

Ibid., 443d.

NE, 1117b. 
Cicero, however, does not follow suit. His fourth virtue, decorum, is in essence the preservation of one's dignity and grace in social relations. Politeness and good manners are one side of it - not making a fool of oneself is the other side. When defining decorum, Cicero refers to the Greek to prepon which refers to fitting, appropriate, wellmannered, well-bred behavior. ${ }^{54} \mathrm{He}$ found it so important that he promoted it to the rank of one of the four main virtues. In Plato, we do not find it at all. In Aristotle the three social virtues of truthfulness, wittiness, and friendliness together with the sense of shame (aidôs) come close. ${ }^{55}$ But Aristotle is far from giving them the weight Cicero gives to decorum.

Regarding the significance of this fourth virtue, the gentleman would, of course, side with Cicero over Plato and Aritotle. Chesterfield's advice to his son to read frequently and with the utmost attention; nay, get by heart, if you can, that incomparable chapter in Cicero's De Officiis upon the to prepon, or the Decorum. It contains whatever is necessary for the dignity of "manners", represents the conviction of most within the aristocratic tradition. ${ }^{56}$ Courtesy and manners were widely seen as at the very core of morality.

So what we have, in essence, is a theory of the soul, including a theory of how it can and should be ordered, as well as a theory of the virtues, in which four virtues are seen as cardinal, but many others circle around them. This was the backbone of the aristocratic moral tradition, of its view of a proper ethos in rulers. The lack of unity in detail between the three sources - Plato, Aristotle, and Cicero - was considered an advantage. It gave different writers within the aristocratic tradition the leeway to vary somewhat, according to their special interests or convictions. Authors that emphasized Christianity more, for instance, tended to assimilate Ciceronian beneficence into biblical agapê.

In short, this system of virtue amounts to a very simple but profound moral ideal of a ruler. A man cannot be a good ruler unless he has the virtues of practical wisdom, fortitude, temperance, and justice. That is to say, above all, a ruler should above all not be a fool, a coward and weakling, unrestrained and irascible, and unjust or unfair.

\section{ARISTOCRATIC CONSTITUTIONAL DESIGN}

Now that we have examined the first question on which virtues a ruler, that is, a nobleman, or a gentleman, should have, let us proceed to the second question - how to turn a nobleman or gentleman into a virtuous ruler. Many, if not most, people today would be glad to see the rulers of democracies possess the traditional virtues. In this respect the aristocratic tradition, although largely forgotten, has certainly not become unacceptable. But when it comes to instilling virtue in rulers, the aristocratic view is commonly judged to be intolerable. Sometimes, however, the good things we want - virtuous rulers - are obtainable only if we accept things we would rather not have but that are in-

\footnotetext{
54 De Off., I.93.

55 NE, 1108a9-1108b1 and NE, bk. IV.6-9.

56 Lord Chesterfield, Letters to his Son and Others, New York 1986 (1929), p. 111.
} 
separable from these good things. It is quite possible that virtue in rulers is obtainable only if the aristocratic way to instill these virtues is also accepted, at least to some degree.

The basic idea is that only the scions of wealthy and old noble families make good rulers, and hence only they should be considered for high public office. At present, this is seen as proof par excellence of the inequity of aristocratic thought, and all societies based on it. But there were actually some good arguments for this idea. ${ }^{57}$

Nobility and wealth are the criteria. "Noble" derives from the verb noscere, "to know," or "to recognize." Thus the root meaning of nobility is something like "to be known by others." The eyes of all are cast on the noble scion from the day of his birth. As Cicero puts it, They examine whatever he does, the very way in which he lives; he is, as it were, bathed in so brilliant a light that no single word or deed of his can be hidden. ${ }^{58}$ The common man, on the other hand, because of his humble and obscure background, is not known. He lives in the shade, as it were. His words and deeds are hidden or capable of being hidden. When it comes to a choice of rulers, it is better to know someone well, than to know him vaguely, or not at all.

But if knowing someone is the point, why not choose anyone who is famous, and about whom the public knows everything? Because fame is not enough. No one wants pop stars or football players to rule the country. Such people usually lack the ability and the gravity to rule. A ruler should ideally come from a family known for its distinguished public service in high office, preferably for many generations. A young man, who grows up in such a family, is provided with two invaluable advantages: the right education and the right examples. First, he has an informal education, from a very early age, of how the country is run, simply by watching from the sideline. Second, he has a number of famous ancestors, some deceased and hanging on the wall in effigy, others alive and kicking in the house, who expect him to emulate them, to become a great statesman himself. Anything else would be failure.

Moreover, wealth gives independence. A wealthy man is a man of independent means. He does not need to earn money, and thus he will probably be less or ideally not at all interested in earning money. Disinterest in earning money inoculates against all kinds of financial temptations, which is an advantage for rulers. Also, he is much freer than others to speak his mind against the powers that be, whether king, parliament, or people. This, too, is important, no so much in ruling but in checking the rulers.

But not just any type of wealth will do. Anyone who has to work long hours to stay wealthy, or who wants to work long hours to become even wealthier, is ruled out. The type of wealth intended is the wealth of the rentier, a man who can and wants to live off of his assets with hardly any work involved. Such a man has the leisure to devote himself to the service of the country. The other wealthy types do not have such leisure.

But it is not enough to be a rentier. One should have inherited one's wealth, not earned it. One's wealth should be old. One should not be a nouveau riche, or a self-made

57 The Roman - especially Ciceronian - background of these ideas is extensively discussed, see in A.A.M. Kinneging, Aristocracy..., ch. 7-8.

58

De Off., II.44. 
man. Such people should be regarded with suspicion, because the passion to become rich necessarily survives after they have "arrived" and wit it comes avarice, materialism, an instrumental view of other men, a focus on market demand, among other undesirable qualities. ${ }^{59}$ These passions are good for making money, but bad when ruling the country. It is best if one is born rich, because chances are much smaller that these base character traits, will develop.

Being born rich has other advantages. There is no need to learn a trade as a young man to make a living. Instead one can be prepared from an early age for rulership. This involves a very different kind of education. What the common man needs to acquire is technical, or instrumental knowledge, knowledge of the means to achieve given ends. And he needs to acquire the moral virtues of the law-abiding, obedient subject. Young men who are being prepared for rulership need a different kind of knowledge, namely that of the goals that are to be pursuedor, in Cicero's words, knowledge of what is good and what is bad. ${ }^{60}$ As mentioned above, this is prudence, or practical wisdom. The education of future rulers should aim at making them prudent men, and should leave the more technical, instrumental types of knowledge to the schooling of the common man.

Another reason why the ruler and the ruled require differing educations is that they must acquire different moral virtues. The moral virtues appropriate to a good ruler include: courage, fortitude, greatness of soul, temperance, decorum, dignity, etc. But perhaps the most important virtues for a ruler are justice and beneficence. In sum, a ruler must have all the virtues discussed in the section above. These virtues must be taught in special schools, where the future rulers are thoroughly prepared for their future public role. This is the reason why even today in Britain such schools, though privately funded, are still called "public."

It is preferable if a ruler's wealth is based on landed property rather than on industry or commerce. Landed property is secure. The yield of the land is relatively stable, whereas the gains of industry and commerce fluctuate wildly. As a result of these fluctuation, one can be wealthy one day and poor the next. With industry and commerce, one has to expend much more time and effort to staying rich. Which in turn means there is little time for leisure. The children of such a wealthy family had better learn the trade in order to protect their wealth instead of going to a "useless" public school.

Owners of landed property, in addition to leisure, have an immovable stake in the country, especially if the land has been in the family for generations and they are thus emotionally attached to it. The owners of industrial or commercial, movable property generally have no local or national attachment. They can and will move their business and home to the other end of the world, if profit opportunities are more promising there. In sum, commerce and industry is the natural playing field of irresponsible nouveaux riches; landed property, on the other hand, is the realm of the responsible aristocratic ruling class. ${ }^{61}$

59 Cf. Tocqueville, Democracy in America, II.2.10.

60 Cicero, De Inventione, II.160.

${ }^{61}$ De Off., I.151. 
Finally, this: there are no rules without exceptions. These aristocratic rules that restrict admission to rulership have exceptions, too. Since antiquity, homines novi, new men, were admitted into the ranks of the ruling class. Cicero himself was a new man. New blood is necessary. New blood prevents inbreeding and the concomitant degeneration. And sometimes the virtues of rulership are mysteriously, but prodigiously present in someone from a very lowly background. On the other hand, openness to new men involves some danger. Too much new blood in a short period of time can easily destroy an aristocratic ethos that was slowly built up through the centuries.

All of this will, of course, sound discordant to the modern, democratic soul. To suggest that there will always be a ruling class, to suggest that this is a good thing, to suggest that the ruling class is superior to the ruled class, to suggest that a different kind of education is proper for this ruling class, to suggest a set of virtues distinct for a ruling class, all appear strange, if not immoral. However, appearances are often deceptive.

Let us end this section with a quotation from Joseph Schumpeter's Capitalism, Socialism, and Democracy (1943). Though Schumpeter is widely quoted, this particular passage is never quoted, probably because it sounds too loudly as undemocratic. Yet, it comes from a section called "Conditions for the Success of the Democratic Method." Schumpeter writes: There may be many ways in which politicians of sufficiently good quality can be secured. Thus far however, experience seems to suggest that the only effective guarantee is in the existence of a social stratum, itself a product of a severely selectiveprocess, that takes to politics as a matter of course. If such a stratum be neither too exclusive nor too easily accessible for the outsider and if it be strong enough to assimilate most of the elements it currently absorbs, it not only will present for the political career products of stocks that have successfully passed many tests in other fields - served, as it were, an apprenticeship in private affairs - but it will also increase their fitness by endowing them with traditions that embody experience, with a professional code and with a common fund of views. ${ }^{62}$

Schumpeter here argues that the presence of such an aristocratic stratum is an important precondition for the survival of democracy. If that is true, the fact that even the idea of it has disappeared in the last few decades is not good news for democracy, contrary appearances notwithstanding. We would do well to remember Aristotle's advice: mêden agan - nothing in excess. Even of democracy, one can have too much. As a result, it would eventually destroy itself. ${ }^{63}$

\section{A CONCLUSION AND A CAVEAT}

In order to survive, democracy needs rulers with an aristocratic ethos. But in order to have rulers possess such an ethos, one needs certain aristocratic familial and educational institutions, of a familial and educational nature, as described in the section above. That is the general idea of this essay.

62 J. Schumpeter, Capitalism..., pp. 290-291.

63 Republic, 562b-564a. 
How realistic is it to expect such an aristocratic ethos? In reality, the ruling class is often rather incompetent and lacking in virtue. Even if aristocratic in name, it is anything but certain that it is also aristocratic in spirit. Rather than the virtues of rulership, the ruling class frequently demonstrates the vices that come so easily with positions of power and honor. The members of the ruling class, past and present, regularly come to think of themselves as infinitely superior to the rest of men. This pride often goes hand in hand with a certain frivolousness of spirit and an excessive attention to external forms. ${ }^{64}$ Worse, because of their pride they are likely to feel that everything is automatically due to them, without any definitive obligations toward those who do not belong to their caste. They look upon outsiders as in a way created to be blind instruments of their aims, passions, and caprices. ${ }^{65}$ In other words, they become insensitive to the plight of ordinary people, and ignorant of their toils and troubles. When this happens, the ruling class has abandoned its public trust, and instead of serving the population, whose well-being should be their highest law, it has become the people's dominus.

Contrary to what many believe, this form of moral corruption is not limited to hereditary ruling classes. Pride comes easily to the human soul. As Mosca tells us, It is amazing, sometimes, to note how quickly people who have managed to climb to high position from humble origins come to consider themselves superior to the rest of mankind ${ }^{66}$ It might even be that such people are psychologically more prone to pride than a hereditary ruling class, if only because they have had to conquer more obstacles than someone destined by birth for high office, and thus they tend to think they have more reason to be proud.

Regular democratic elections can, to some degree, curb this tendency in the human soul, but, elections can also serve as an incentive to other forms of moral corruption in the ruling class, such as lying, flattering, making promises one cannot keep, fomenting prejudices, and playing on primitive instincts. Moreover, those who are good at this vicious game regularly take pride in it, and often come to think of themselves as infinitely superior to the rest of men.

Thus, democracy certainly does not crush the phenomenon of pride in the ruling class. That vice cannot be cured merely by institutional design. It is rooted too deeply within the human soul. Again, ethos is of the utmost importance. Members of the ruling class should be deeply aware of the fact that they are prone to all human failings, especially since many of these failings are triggered by positions of power and honor. And rulers should fight these temptations within their own souls. The most vicious of all the human failings is pride, but there are many others. Any acquisition of virtue necessarily begins with eliminating vice.

Can this renunciation of vice be achieved? The Xenophontic parable of Heracles on the crossroads, having to choose between an easy path of vice and a difficult path of virtue, was an endlessly repeated commonplace in the aristocratic tradition. ${ }^{67}$ And

64 G. Mosca, The Ruling Class, p. 420.

65 Ibid.

66 Ibid.

67 Xenophon, Memorabilia, II.1.21. 
warnings against pride and the other vices were rife. ${ }^{68}$ The unrelenting endorsement of the virtues in the aristocratic tradition is paired with an equally unrelenting warning against the vices or sins. For all of which there were abundant sources in ancient Greek and Roman texts, as well as in the biblical tradition, which, to a large extent was believed to say the same or compatible things.

That such attempts to curb vice and arouse virtue were often in vain bespeaks the wickedness of human nature and its resistance to moral improvement. It is certain, however, that without at least a degree of aristocratic ethos, the ruling class will always be rather more the enemy than the guardian of the people. Not least in a democracy.

\section{BIBLIOGRAPHY}

Allman D., Beatty M. (eds.), Cultivating Citizens. Soulcraft and Citizenship in Contemporary America, Lanham 2003 (Applications of Political Theory).

Anthony D., De la République et de la citoyenneté. Le défi démocratique dans la France du XXIe siècle, Besançon 2009.

Aristotle, De Anima.

Aristotle, Eudemian Ethics.

Aristotle, Nicomachean Ethics.

Aron R., Les sociétés modernes, Paris 2006 (Quadrige. Grands Textes).

Behrens C.B.A., Society, Government, and the Enlightenment. The Experiences of Eighteenth-Century France and Prussia, New York 1985.

Burke P., The Fortunes of the Courtier. The European Reception of Castiglione's Cortegiano, Cambridge 1995.

Carré J. (ed.), The Crisis of Courtesy. Studies in the Conduct-Book in Britain, 1600-1900, Leiden 1994 (Brill's Studies in Intellectual History, 51).

Chaussinand-Nogaret G., La noblesse au XVIIIe siècle. De la féodalité aux lumières, Paris 1976.

Lord Chesterfield, Letters to his Son and Others, New York 1986.

Cicero, De Finibus Bonorum et Malorum.

Cicero, De Inventione.

Cicero, De Natura Deorum.

Cicero, De Officiis.

Cicero, Stoicorum Paradoxa.

Cicero, Tusculanae Disputationes.

Dahl R., Democracy and its Critics, New Haven 1989.

Dewey J., Democracy and Education. An Introduction to the Philosophy of Education, New York 2016 (Text-Book Series in Education).

Dyck A., A Commentary on Cicero, De Officiis, Ann Arbor 1996.

Evans R., The Coming of the Third Reich, New York 2005.

Grafton A. et al. (eds.), The Classical Tradition, Cambridge 2010.

68 E.g. De Off., I.90. 
Gutmann A., Democratic Education, Princeton 1999.

Kant I., 'Zum ewigen Frieden' in idem, Werke, Vol. 6, ed. W. Weischedel, Darmstadt 1998.

Kinneging A.A.M., Aristocracy, Antiquity, and History. Classicism in Political Thought, New Brunswick, N.J. 1997.

Kinneging A.A.M., Geography of Good and Evil. Philosophical Investigations, transl. by I. Hardy, ed. by J. Price, Wilmington 2009 (Crosscurrents).

Lachaud F., Scordia L. (eds.), Le Prince au miroir de la littérature politique de l'Antiquité aux Lumières, Mont-Saint-Aignan 2007.

Lijphart A., Patterns of Democracy. Government Forms and Performance in Thirty-Six Countries, New Haven 1999.

MacKendrick P., The Philosophical Books of Cicero, Duckworth 1995.

Meredith M., The State of Africa; a History of the Continent since Independence, London 2005.

Mosca G., The Ruling Class, transl. by H. Kahn, ed. and rev. by A. Livingstone, New York-London 1939.

Rawls J., A Theory of Justice, rev. ed., Cambridge 1999.

Riklin A., Machtteilung. Geschichte der Mischverfassung, Darmstadt 2006.

Rossetti W.M., Italian Courtesy-Books, London 1869 (Early English Text Society, 8).

Sartori G., Homo videns. Televisione e post-pensiero, Roma 1997 (Sagittari Laterza, 107).

Sartori G., The Theory of Democracy Revisited, Vol. 1-2, Chatham, N.J. 1987.

Schumpeter J., Capitalism, Socialism, and Democracy, London-New York 1994.

Shklar J., 'The Liberalism of Fear' in eadem, Political Thought and Political Thinkers, ed. S. Hoffmann, Chicago 1998.

Singer B., Die Fürstenspiegel in Deutschland im Zeitalter des Humanismus und der Reformation. Bibliographische Grundlagen und ausgewählte Interpretationen. Jakob Wimpfeling, Wolfgang Seidel, Johann Sturm, Urban Rieger, München 1980 (Humanistische Bibliothek. Reibe 1. Abhandlungen, 34).

Vile M.J.C., Politics in the USA, London-New York 2007.

Zielinski Th., Cicero im Wandel der Jahrhunderte, Leipzing-Berlin 1929.

Prof. Andreas KINNEGING - has an M.A. in political science from the University of Nijmegen, and a Ph.D in law from the University of Leiden. His Ph.D dissertation also appeared as a book, entitled Aristocracy, Antiquity, and History (Brunswick, N.J. 1994). He holds the Chair in Legal Philosophy at the Law Faculty of the University of Leiden. His main fields of interest are legal and political theory, ethics, constitutional theory, history of ideas, and constitutional law. He published in all of these fields. He authored six books in total, and edited sixteen books, among which the first complete Dutch translation of Tocqueville's Democracy in America and the three volumes of the English translation of Nicolai Hartmann's seminal work Ethics. His book Geografie van Goed en Kwaad (Utrecht 2005) was awarded the Socrates-prize 2006, for the best Dutch book of the year in the field of philosophy. In 2009 an English translation appeared under the title Geography of Good and Evil. He is an award winning teacher. 